\title{
Long-term efficacy and tolerability of pentosan polysulphate sodium in the treatment of bladder pain syndrome
}

\author{
Ali A. Al-Zahrani, MD; Jerzy B. Gajewski, MD, FRCSC
}

See related article on page 119.

\section{Abstract}

Objective: The primary objective of this study is to report on the long-term efficacy and tolerability of pentosan polysulphate sodium (PPS) in patients with bladder pain syndrome (BPS). The secondary objective is to find the predictors of the long-term outcome.

Methods: This is a single institution, retrospective study. The study period was from 1994 to 2008. All patients fulfilled the clinical criteria of BPS, as suggested by European Society for the Study of Interstitial Cystitis. We included only patients with de novo BPS diagnosis and no previous PPS or other treatment. The efficacy of PPS was measured with the global response assessment scale (GRA). Patients were stratified into 2 groups based on the duration of the treatment. Group 1 took the drug for less than 12 months. Group 2 took the drug for more than 12 months.

Results: There were 271 patients eligible for the study. Most of the patients were female $(90 \%)$, with the mean age at presentation of 45.5 years. The average duration of symptoms was 28.5 months. The mean follow-up was 22 months (range 3-130). Out of all the patients, 147 patients (54.2\%) reported over 50\% improvement using the GRA. The reported efficacy was higher in Group 2 (60\%). Ninety-three patients (34.3\%) decided to stop taking the medication for various reasons. The most common reasons to stop the medication were poor outcome (16.6\% of patients) and side effects (11.1\% of patients). Poor outcome was associated with nocturia, smoking and detrusor overactivity. Good outcome was associated with longer PPS intake (>12 months) and severe cystoscopic findings of glomerulation.

Conclusion: Pentosan polysulphate sodium is an effective oral therapy to control the symptoms of BPS with good long-term efficacy and tolerability.

Cite as: Can Urol Assoc J 2011;5(2):113-8; D0l:10.5489/cuaj.10095

\section{Résumé}

Objectif : Le principal objectif de cet article est de faire état de l'efficacité et de la tolérabilité à long terme du polysulfate de pentosan sodique (PPS) chez des patients atteints de cystite interstitielle. L'objectif secondaire est de dégager des facteurs de prédiction des résultats à long terme.

Méthodologie : Il s'agit d'une étude rétrospective menée dans un seul centre. L'étude a été menée entre 1994 et 2008. Tous les patients répondaient aux critères cliniques d'une cystite intersti- tielle, tels qu'avancés par la European Society for the Study of Interstitial Cystitis. Nous n'avons inclus que des cas nouvellement diagnostiqués de cystite interstitielle, et aucun cas déjà traité par PPS ou par d'autres moyens. L'efficacité du PPS a été mesurée par l'échelle d'évaluation globale de la réponse (échelle GRA). Les patients ont été stratifiés en deux groupes en fonction de la durée du traitement. Le groupe 1 a pris le médicament pendant moins de 12 mois. Le groupe 2 a pris le médicament pendant plus de 12 mois.

Résultats : Au total, 271 patients étaient admissibles à l'étude. La plupart des patients étaient des femmes (90\%), et l'âge moyen au moment de l'inscription était de 45,5 ans. La durée moyenne des symptômes était de 28,5 mois. Le suivi moyen était de 22 mois (de 3 à 130). Sur le total des patients, 147 (54,2\%) ont signalé une amélioration de plus de $50 \%$ selon I'échelle GRA. L'efficacité signalée était plus élevée dans le groupe 2 (60\%). Quatre-vingttreize patients $(34,3 \%)$ ont décidé de cesser de prendre le médicament pour diverses raisons. Les raisons les plus souvent invoquées pour justifier l'arrêt du traitement étaient le manque d'efficacité (16,6\% des patients) et les effets secondaires (11,1\% des patients). Le manque d'efficacité était associé à une nycturie, au tabagisme et à une hyperactivité du détrusor. Un bon résultat a été associé à une prise du PPS sur une période plus longue (>12 mois) et de graves signes de glomérulation observés par cystoscopie.

Conclusion : Le polysulfate de pentosan sodique est un traitement par voie orale efficace pour maîtriser les symptômes de cystite interstitielle et est doté d'un bon profil d'efficacité et de tolérabilité à long terme.

\section{Introduction}

Bladder pain syndrome (BPS) is a chronic debilitating clinical syndrome of pain or discomfort in the pelvic area perceived to be related to the bladder. The patient should have at least one or more urinary tract symptom. ${ }^{1}$ Bladder pain syndrome mainly affects women and is much more prevalent than previously thought. In a population-based study, Curhan and colleagues estimated that $0.5 \%$ of women are affected by BPS. ${ }^{2}$ These symptoms have a profound effect on patients' quality of life. ${ }^{3}$

The etiology of BPS is still unclear, although several theories have been proposed, including autoimmune responses, neurogenic causes and increased permeability of the bladder 
epithelium. ${ }^{4}$ The bladder urothelium is naturally coated with a layer of glycosaminoglycan (GAG) that has been shown to be defective in BPS patients. ${ }^{5}$ The malfunction of this layer may allow migration of urine solute transepithelially and provoke symptoms. ${ }^{6}$ Some reports, however, did not find a difference in the GAG layer between BPS and control patients. ${ }^{7-8}$

Oral pentosan polysulphate sodium (PPS) is approved by Health Canada and the FDA for symptoms associated with BPS. The widely accepted theory for the mechanism of action PPS is that it substitutes the deficiency in the GAG layer. ${ }^{9}$ The short-term safety and efficacy of PPS have been demonstrated by several randomized clinical trials. ${ }^{10-11}$ However, long-term data are still limited. We report the long-term results and the factors that may predict the outcome of PPS in the treatment of BPS.

\section{Methods}

The study was approved by our institutional review board. This is a retrospective study for patients with a diagnosis of BPS and who took PPS from 1994 to 2008. The clinical criteria for BPS were based on International Society for the Study of Bladder Pain Syndrome (ESSIC) proposal. ${ }^{1}$

Patients were evaluated by medical history, physical examination, urine culture, urodynamic study and cystoscopic examination. Patients were interviewed at the clinic and their symptoms were recorded before starting the therapy. All patients had pelvic pain or pressure perceived to be related to bladder filling. All patients had cystoscopic examination with hydrodistention under general anaesthesia to exclude confusable disease and to grade the severity of the disease. ${ }^{1}$ Nordling and colleagues described the cystoscopic classification of the disease severity. ${ }^{12}$ Grades I and II were considered mild in severity, while grades III and IV were labelled as severe disease.

The criteria for bladder outlet obstruction during the urodynamic study were based on the obstruction coefficient value above 0.35 in females ${ }^{13}$ and the bladder outlet obstruction index above 40 in males. ${ }^{14}$

In this study, only patients with de novo PPS prescription were enrolled. All patients were followed at 3, 6 and 12 months after the diagnosis and yearly thereafter except if clinically indicated. Only patients with a minimum followup of 3 months were included. All patients were instructed to follow the BPS diet. ${ }^{15}$

The criteria of clinical success were based on the global response assessment (GRA) scale of 6 items: worsening of symptoms (less than $0 \%$ ), no change $(0 \%)$, mild improvement (less than 50\%), moderate improvement (50\%-75\%), marked improvement (more than 75\%) and completely cured $(100 \%) .{ }^{10}$ Adverse events during follow-up were recorded.

Patients with urinary tract malignancy, urinary tract infec- tion, pelvic radiation therapy, chemotherapy, urogenital prolapse, urethral diverticulum, endometriosis, obstetric malignancy or urinary retention were excluded from the study. ${ }^{1}$

Information on patients' demographic factors, symptoms at presentation, urodynamic results and cystoscopic findings was included. Patients were divided into 2 groups based on the duration of PPS intake: Group 1 took the drug for more than 3 months but less than 12 months; Group 2 took the drug for more than 12 months.

Statistical analysis was carried out using the commercially available software (SPSS v17, SPSS Inc., Somers, NY). Unpaired t-test for parametric variable and Mann-Whitney test for non-parametric variables were used. The categorical variables were analyzed with Chi Square test. Statistical significance was two-sided and set at $p<0.05$.

\section{Results}

Based on the inclusion criteria, 271 patients were eligible for the study. Most patients were female (90\%) and the mean age at presentation was 45.5 years (standard deviation $[\mathrm{SD}] \pm 13.9)$. The average duration of symptoms was 28.5 months (range 6-120) (Table 1).

All patients had chronic suprapubic pain or discomfort perceived to be related to the bladder. At least 1 other storage urinary symptom was present in the enrolled patients (Fig 1).

Cystoscopic examination under general anesthesia was done in all patients. Mild to moderate disease was found in 216 patients $(79.7 \%)$, while the severe form was found in 55 patients $(21.3 \%)$. The average maximum anesthetic bladder capacity was $659.1 \mathrm{~mL}(\mathrm{SD} \pm 147.4$ ) (Table 2 ). There were no anatomical causes for the bladder outlet obstruction in the obstructed patients during the cystoscopic examination.

Urodynamics were available in 259 patients (95.5\%). The mean free voiding volume was $191.7 \mathrm{~mL}(\mathrm{SD} \pm 147)$, while the mean maximum cystometric bladder capacity was $250.2 \mathrm{~mL}$ ( $\mathrm{SD} \pm 134.4$ ). Detrusor overactivity on filling cystometry study was found in 38 patients $(14 \%)$. Pressure flow study was attempted for all patients, however only 131 patients $(50.5 \%)$ could void during the test. Mild to moderate bladder outlet obstruction were present in 72 patients (54.9\%).

Table 1. Patients' demographic data

\begin{tabular}{|c|c|c|c|}
\hline Variable & & Mean/number & $\begin{array}{c}\text { Standard de } \\
\text { viation/ } \\
\text { percentage }\end{array}$ \\
\hline Age & & 45.55 years & \pm 13.9 \\
\hline \multirow[t]{2}{*}{ Gender } & Female & 244 & $(90 \%)$ \\
\hline & Male & 27 & $(10 \%)$ \\
\hline $\begin{array}{l}\text { Symptoms } \\
\text { duration }\end{array}$ & & 28.49 months & \pm 25.4 \\
\hline
\end{tabular}




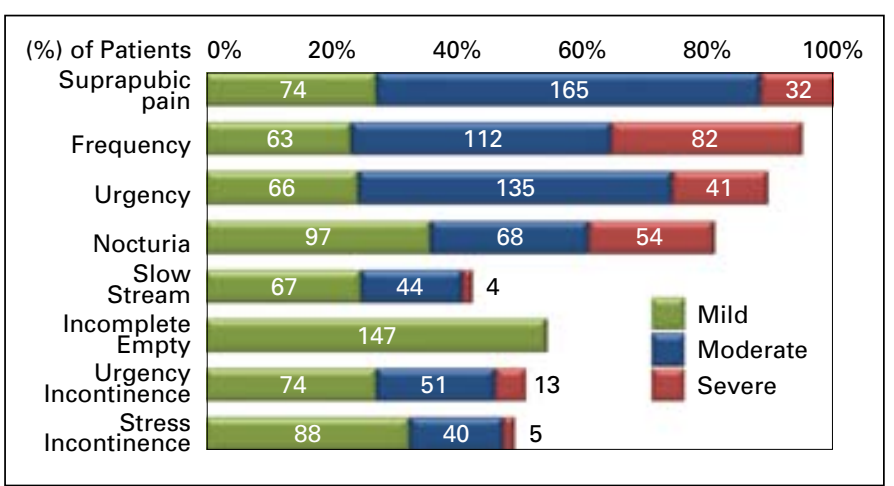

Fig. 1. Patients presenting symptoms.

With a mean follow-up of 22 months (range 3-131), 147 patients $(54.2 \%)$ reported more than $50 \%$ improvement in the GRA with PPS. There was mild improvement in additional 55 patients (20.2\%). The degree of improvement was higher in patients with more than 12 months of PPS intake $(60 \%$ vs. $40 \%)$; however, it was not statistically significant $(p=0.09)$ (Fig. 2). Ninety-three patients (34.3\%) decided to stop taking the medication for various reasons (Fig. 3). The most common reason patients stopped the medication was poor response in 45 patients $(16.6 \%)$. Other reasons included side effects in 30 patients $(11.1 \%)$, resolution of the BPS symptoms in 11 patients $(4.1 \%)$ and financial reasons in 6 patients $(2.2 \%)$ (Table 3$)$.

The side effects that resulted in PPS discontinuation included stomach upset in 23 patients $(8.5 \%)$, headache in 6 patients $(2.2 \%)$, hair loss in 3 patients $(1.1 \%)$, hypersensitivity in 3 patients $(1.1 \%)$ and increase in liver enzymes in 2 patients $(0.7 \%)$ (Table 4$)$.

Patients with detrusor overactivity had poorer outcome with $p$ values of 0.037 . In group 2, patients with severe disease at cystoscopy had better outcomes $(p=0.013)$, while patients with higher grade of nocturia had poorer outcomes $(p=0.01)$ (Table 5). A history of smoking affected the over-

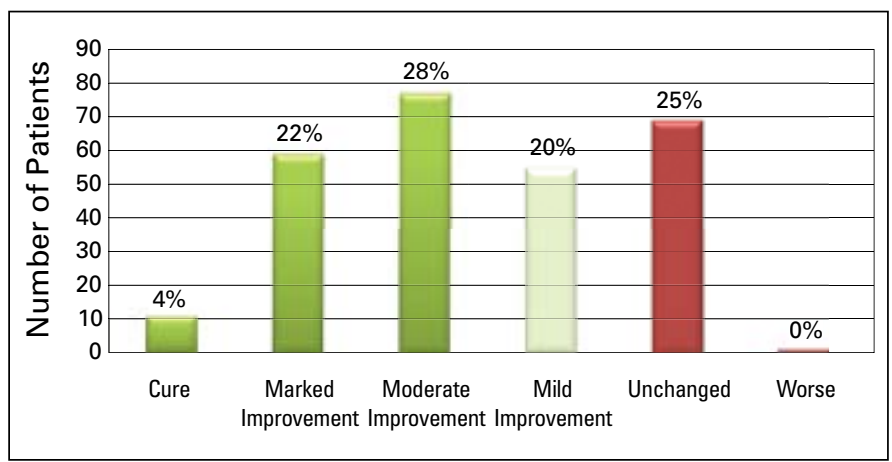

Fig. 2. Grade of improvement with pentosan polysulphate sodium.

all discontinuation rate. In group 1, 34.8\% of patients who discontinued the PPS had a history of smoking compared to $16.1 \%$ of patients who had continued to take PPS ( $p=0.01$ ).

\section{Discussion}

The Interstitial Cystitis Database considers PPS one of the most frequently prescribed oral drugs for BPS in United States. ${ }^{16}$ The FDA approved PPS for the treatment of BPS in 1996. There is, however, a limited long-term report on its efficacy and tolerability. ${ }^{17}$

The clinical efficacy of PPS has been reported in several short-term, randomized, controlled studies. Improvement in these studies ranged from $28 \%$ to $45 \%$ in PPS group versus $13 \%$ to $18 \%$ in the placebo group. ${ }^{10-11,18}$ The clinical response usually observed after 4 to 8 weeks of PPS. ${ }^{19}$ Parsons and Mulholland reported the reappearance of symptoms after stopping PPS within 3 to 12 weeks. ${ }^{18}$ The severity of BPS symptoms is well known to fluctuate. Held and colleagues reported that $30 \%$ to $46 \%$ of BPS patients can go into remission for an average of 8 months. ${ }^{20}$ This symptom fluctuation is important in reporting the long-term efficacy of PPS.

Our study showed that $50 \%$ of patients reported at least moderate improvement during the first 12 months of follow-

Table 2. Urodynamic versus cystoscopic findings

\begin{tabular}{|c|c|c|c|}
\hline \multirow{3}{*}{ Urodynamic variable } & \multirow{3}{*}{ Overall } & \multicolumn{2}{|c|}{ Cystoscopic findings } \\
\hline & & Glomerulation & Hunner's lesion \\
\hline & & $\mathrm{N}=216(79.7 \%)$ & $\mathrm{N}=55(21.3 \%)$ \\
\hline Maximum flow rate & $13.6 \mathrm{~mL} / \mathrm{s}( \pm 8)$ & $14.2( \pm 8.1)$ & $11.1( \pm 7.8)$ \\
\hline Voided volume & $191.7 \mathrm{~mL}(147 \pm)$ & $207.1( \pm 149.7)$ & $128.9( \pm 119.7)$ \\
\hline Post void residual & $60.1 \mathrm{~mL}( \pm 92.1)$ & $62.6( \pm 94.7)$ & $50.1( \pm 80.9)$ \\
\hline First sensation of bladder filling & $137.5 \mathrm{~mL}( \pm 104.7)$ & $140.6( \pm 108.6)$ & $124.7( \pm 86.7)$ \\
\hline Maximum cystometric capacity & $250.2 \mathrm{~mL}( \pm 134.4)$ & $259.4( \pm 134.2)$ & $212.4( \pm 129.8)$ \\
\hline Detrusor overactivity & $38(14 \%)$ & $33(15.3 \%)$ & $5(9.1 \%)$ \\
\hline Bladder outlet obstruction & $72(54.9 \%)$ & $59(57.1 \%)$ & $13(51.2 \%)$ \\
\hline $\begin{array}{l}\text { Detrusor pressure at maximum } \\
\text { flow rate (Pdet.Qmax.) }\end{array}$ & $30.5 \mathrm{~cm} \mathrm{H}_{2} \mathrm{O}( \pm 19.4)$ & $30.9( \pm 19.8)$ & $28.63( \pm 17.4)$ \\
\hline $\begin{array}{l}\text { Maximum cystoscopic bladder } \\
\text { capacity (general anesthesia) }\end{array}$ & $659.1 \mathrm{~mL}( \pm 147.4)$ & $664.1( \pm 143.9)$ & $639.7( \pm 159.9)$ \\
\hline
\end{tabular}




\begin{tabular}{lcc}
\hline $\begin{array}{l}\text { Table 3. Causes of pentosan polysulphate sodium } \\
\text { discontinuation }\end{array}$ & No. patients & Percentage \\
\hline Causes & 45 & $16.6 \%$ \\
\hline No efficacy & 30 & $11.1 \%$ \\
Side effect & 11 & $4.1 \%$ \\
Remission & 6 & $2.2 \%$ \\
Too Expensive & 2 & $0.7 \%$ \\
Other & & \\
\hline
\end{tabular}

up. This rate had increased to $60 \%$ for patients with longer than 12 months of follow-up. Up to $66 \%$ of patients were still taking the medication at the end of the study, with an average follow up of 22 months (range 3-131). Most patients had to pay for their medication and only a few of them had medical insurance. Jepsen and colleagues reported the long-term results in 97 patients with a follow-up of up to 16 months. ${ }^{21}$ They noticed that initially, $50 \%$ of patients had good outcomes, but at the end only $18.7 \%$ had maintained their response rate. Most patients in their series discontinued treatment due to relapse or side effects. A more recent series of 380 patients, with longer follow-up, was reported by Nickel and colleagues. Their study demonstrated that $17 \%$ to $23 \%$ of patients were responders by 4 weeks and the rate increased to $59 \%$ to $67 \%$ at the 32 -week mark of the study. ${ }^{22}$ Hanno and colleagues reported that $42 \%$ to $62 \%$ of patients reached moderate improvement and over the GRA with follow-up up to 35 months. They found that the efficacy reached the maximum by 6 to 11 months of therapy, with no further change or deterioration with continued therapy. ${ }^{23}$

Pentosan polysulphate sodium is generally well-tolerated with few toxicities and adverse events. ${ }^{11,19}$ In our series, the overall discontinuation rate due to adverse events was $11.1 \%$. The most common adverse event was gastrointes-

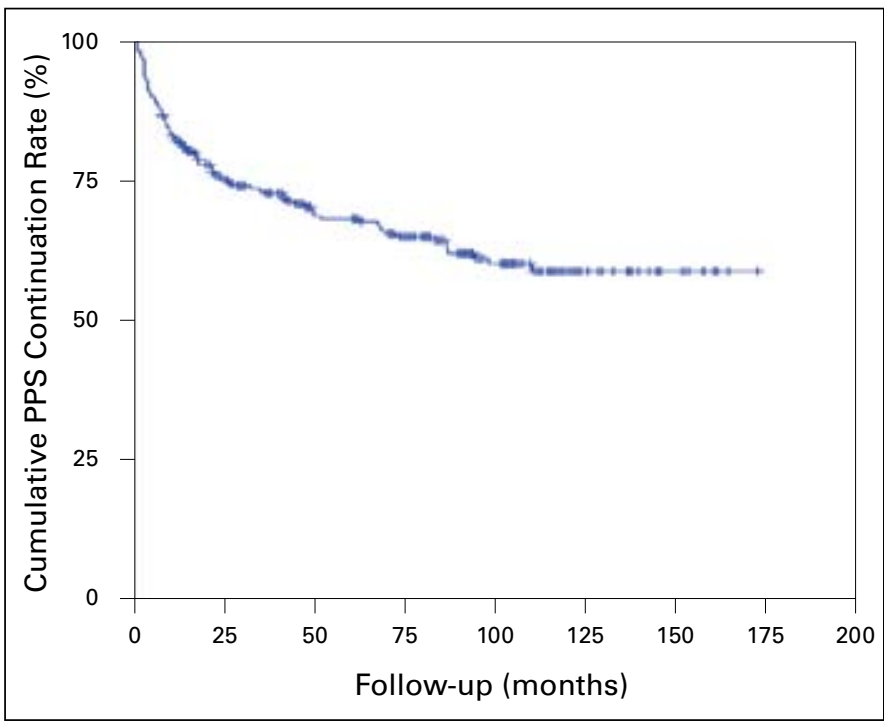

Fig. 3. Kaplan-Meier Curve for the pentosan polysulphate sodium continuation rate.

\begin{tabular}{lcc}
$\begin{array}{l}\text { Table 4. The reported side effects of pentosan polysulphate } \\
\text { sodium therapy }\end{array}$ & No. patients & Percentage \\
\hline Side effect & 22 & $8.1 \%$ \\
\hline Stomach upset & 5 & $1.8 \%$ \\
Headache & 3 & $1.1 \%$ \\
Hair loss & 3 & $1.1 \%$ \\
Hypersensitivity & 2 & $0.7 \%$ \\
Elevated liver enzymes & 1 & $0.4 \%$ \\
Nausea & 1 & $0.4 \%$ \\
Dizziness & &
\end{tabular}

tinal upset and abdominal pain (8.5\%), followed by headache $(2.2 \%)$. Alopecia was rare $(1.1 \%)$ and it was reversible. Discontinuation due to adverse events in the Hanno report was $4 \%$ and it was mainly reversible alopecia (3.91\%). ${ }^{23}$ The most common adverse events in the Nickel long-term report were diarrhea $(25.3 \%)$, headache $(18.2 \%)$, nausea $(15.0 \%)$, pelvic pain $(12.9 \%)$, abdominal pain $(12.6 \%)$ and alopecia (5.5\%). Diarrhea and abdominal pain were doserelated. Nickel and colleagues concluded that $22.4 \%$ of patients discontinued treatment because of dose-related adverse effects. ${ }^{22}$

Nocturia was the only symptom of BPS that showed a correlation with PPS outcome. Patients with nocturia and more than 12 months of follow-up showed a trend toward less efficacy of the treatment $(p=0.01)$. Holm-Bentzen and colleagues followed 106 patients for 3 months. Patients had improvement with PPS therapy regarding pain, frequency and urgency, but not the nocturia. ${ }^{24}$

Detrusor overactivity was associated with a poor response to treatment in our study. This finding was more prominent during the first 12 months of follow-up. More than $50 \%$ of the patients who did have the pressure flow study showed evidence of bladder outlet obstruction. A similar finding was reported by Cameron and Gajewski in 231 patients with BPS. ${ }^{25} \mathrm{~A}$ possible mechanism of this finding is external sphincter ${ }^{26}$ or pelvic floor ${ }^{27}$ spasticity due to the pain. The severity of the disease during cystoscopy was another prognostic finding in the study. However, the difference was evident only in Group 2 who was followed for more than 12 months. Hanno and colleagues noticed that the maximum responder percentages were not reached until after 23 months of follow-up. ${ }^{23}$ Patients with severe symptoms had better response to the increase of PPS dose to $600 \mathrm{mg}$ in Nickel's dose-ranging study. ${ }^{22}$ Jepsen and colleagues found that better responses were seen in patients with less constant pain at baseline and not related to the cystoscopic finding. ${ }^{21}$

A history of current smoking during the PPS therapy correlated with the overall discontinuation rate, and it was statistically significant during the first 12 months of follow-up $(34.8 \%$ vs. $16.1 \%)(p=0.009)$. The correlation between BPS and smoking is controversial. Leppilahti and colleagues did not find any association. ${ }^{28}$ However, 2 recent studies 
Table 5: Variable Analysis of the PPS Therapy Outcome

\begin{tabular}{|c|c|c|c|c|c|c|c|c|c|}
\hline \multirow{2}{*}{ Factor } & \multicolumn{3}{|c|}{ Overall ( $n=271)$} & \multicolumn{3}{|c|}{$\begin{array}{l}\text { Less than } 12 \text { months of follow up } \\
\qquad(n=160)\end{array}$} & \multicolumn{3}{|c|}{$\begin{array}{l}\text { More than } 12 \text { months of follow up } \\
\text { (n=111) }\end{array}$} \\
\hline & $\begin{array}{l}\text { Good out- } \\
\text { come }\end{array}$ & $\begin{array}{l}\text { Poor out- } \\
\text { come }\end{array}$ & $p$ value & $\begin{array}{l}\text { Good out- } \\
\text { come }\end{array}$ & $\begin{array}{l}\text { Poor out- } \\
\text { come }\end{array}$ & $p$ value & $\begin{array}{l}\text { Good out- } \\
\text { come }\end{array}$ & $\begin{array}{l}\text { Poor out- } \\
\text { come }\end{array}$ & $p$ value \\
\hline \multicolumn{10}{|l|}{ Symptoms } \\
\hline - Suprapubic pain ${ }^{f}$ & & & 0.52 & & & 0.35 & & & 0.99 \\
\hline - Mild & $43(29.3 \%)$ & $31(25 \%)$ & & $29(36.3 \%)$ & $22(27.5 \%)$ & & $14(20.9 \%)$ & $9(20.5 \%)$ & \\
\hline - Moderate & $85(57.8 \%)$ & $80(64.5 \%)$ & & $43(53.8 \%)$ & $52(65 \%)$ & & $42(62.7 \%)$ & $28(63.6 \%)$ & \\
\hline - Severe & $19(12.9 \%)$ & $13(10.5 \%)$ & & $8(10 \%)$ & $6(7.5 \%)$ & & $11(16.4 \%)$ & 7 (15.9\%) & \\
\hline - Frequency ${ }^{£}$ & & & 0,24 & & & 0.18 & & & 0.15 \\
\hline - Mild & $40(28.8 \%)$ & $23(19.5 \%)$ & & $22(27.5 \%)$ & $16(20 \%)$ & & $18(26.9 \%)$ & 7 (15.9\%) & \\
\hline - Moderate & $64(46 \%)$ & $48(40.7 \%)$ & & $34(42.5 \%)$ & $29(36.3 \%)$ & & $30(44.8 \%)$ & $19(43.2 \%)$ & \\
\hline - Severe & $35(25.2 \%)$ & 47 (39.8\%) & & $20(25 \%)$ & 30 (37.5\%) & & $15(22.4 \%)$ & $17(38.6 \%)$ & \\
\hline - Urgency ${ }^{\mathrm{f}}$ & & & 0.12 & & & 0.10 & & & 0.73 \\
\hline - Mild & $40(29.6 \%)$ & $26(24.3 \%)$ & & $23(28.8 \%)$ & $15(19.2 \%)$ & & $17(25.4 \%)$ & $11(25.6 \%)$ & \\
\hline - Moderate & $78(57.8 \%)$ & 57 (53.3\%) & & $43(53.8 \%)$ & 37 (47.4\%) & & $35(52.2 \%)$ & 20 (46.5\%) & \\
\hline - Severe & $17(12.6 \%)$ & $24(22.4 \%)$ & & $8(10.8 \%)$ & $16(20.5 \%)$ & & $9(13.4 \%)$ & $8(18.6 \%)$ & \\
\hline - Nocturia ${ }^{\mathrm{f}}$ & & & 0.09 & & & 0.82 & & & 0.01 \\
\hline - Mild & 57 (48.7\%) & $40(39.2 \%)$ & & $30(37.5 \%)$ & $28(35.4 \%)$ & & $27(40.3 \%)$ & $12(27.3 \%)$ & \\
\hline - Moderate & $38(32.5 \%)$ & $30(29.4 \%)$ & & 19 (23.8\%) & $21(26.6 \%)$ & & 19 (28.4\%) & $9(20.5 \%)$ & \\
\hline - Severe & $22(18.8 \%)$ & $32(31.4 \%)$ & & $14(17.5 \%)$ & $17(21.5 \%)$ & & $8(11.9 \%)$ & $15(34.1 \%)$ & \\
\hline \multicolumn{10}{|l|}{ Urodynamic Findings } \\
\hline $\begin{array}{l}\text { - Maximum } \\
\text { flow rate* }\end{array}$ & 14.2 & 12.8 & 0.21 & 15.77 & 12.62 & 0.07 & 12.6 & 13.2 & 0.79 \\
\hline - Voided volume* & 200.1 & 181.6 & 0.30 & 213.3 & 179.3 & 0.16 & 185.9 & 185.7 & 0.90 \\
\hline $\begin{array}{l}\text { - Maximum } \\
\text { cystometric capacity }\end{array}$ & 262 & 236.2 & 0.31 & 273.75 & 219.9 & 0.06 & 248.1 & 264.1 & 0.58 \\
\hline $\begin{array}{l}\text { - Detrusor } \\
\text { overactivity }\end{array}$ & & & $\underline{0.033}$ & & & $\underline{0.046}$ & & & 0.16 \\
\hline - Present & $15(11.5 \%)$ & $23(21.7 \%)$ & & $5(6.9 \%)$ & $12(17.6 \%)$ & & $10(16.9 \%)$ & $11(28.9 \%)$ & \\
\hline - Absent & $116(88.5 \%)$ & $83(78.3 \%)$ & & $67(93.1 \%)$ & $56(82.4 \%)$ & & $49(83.1 \%)$ & $27(71.1 \%)$ & \\
\hline $\begin{array}{l}\text { - Bladder outlet } \\
\text { obstruction }\end{array}$ & & & 0.9 & & & 0.31 & & & 0.28 \\
\hline - Present & $37(52.1 \%)$ & $35(52.2 \%)$ & & $16(40 \%)$ & $21(51.2 \%)$ & & $21(67.7 \%)$ & $14(53.8 \%)$ & \\
\hline - Absent & $34(47.9 \%)$ & $32(47.8 \%)$ & & $24(60 \%)$ & $20(48.8 \%)$ & & $10(32.3 \%)$ & $21(46.2 \%)$ & \\
\hline Cystoscopic finding ${ }^{f}$ & & & 0.11 & & & 0.85 & & & $\underline{0.01}$ \\
\hline - Glomerulation & $112(76.2 \%)$ & $104(83.9 \%)$ & & $62(77.5 \%)$ & $63(78.8 \%)$ & & $50(74.6 \%)$ & $41(93.2 \%)$ & \\
\hline - Hunner's lesions & $35(23.8 \%)$ & $20(16.1 \%)$ & & $18(22.5 \%)$ & $17(21.3 \%)$ & & $17(25.4 \%)$ & $3(6.8 \%)$ & \\
\hline Cystoscopic capacity ${ }^{*}$ & 657.9 & 660.5 & 0.89 & 646.1 & 647.5 & 0.95 & 672.4 & 684.1 & 0.66 \\
\hline
\end{tabular}

have shown that smoking increases the risk of bladder pain in BPS patients by at least 2.3-fold. ${ }^{29,30}$ Tobacco may alter the permeability of bladder epithelial cells, allowing the penetration of allergens, chemicals, drugs or toxins into the bladder wall and aggravate the BPS symptoms.

Our study has some obvious limitations. First, the study is retrospective in nature. Second, the outcome was measured only with the GRA. However, the median follow-up in our study was 22 months. We have reported detailed adverse events and the reasons for discontinuation.

\section{Conclusion}

Pentosan polysulphate sodium is an effective oral therapy to control the symptoms of BPS with good long-term efficacy and tolerability. Severe nocturia, a history of smoking and the presence of detrusor overactivity might predict poor outcomes. Longer PPS therapy in patients with severe cystoscopic findings of BPS might be necessary to achieve better outcomes.

Urology Department, Dalhousie University, Halifax, NS 
Al-Zahrani et al.

We would like to thank Dr. Greg Bailly from the Department of Urology, Dalhousie University, for his support and help in reviewing the manuscript.

Competing interests: None declared.

This paper has been peer-reviewed.

\section{References}

1. Van De Merwe J, Nordling J, Bouchelouche K, et al. Diagnostic criteria, classification, and nomenclature for painful bladder syndrome/intersitial cysitis: an ESSIC proposal. Eur Urol 2008;53:60-7

2. Curhan GC, Speizer FE, Hunter DJ, et al. Epidemiology of interstitial cystitis: a population based study. J Urol 1999;161:549-52.

3. Michael YL, Kawachi I, Stampfer MJ, et al. Quality of life among women with interstitial cystitis. J Urol 2000;164:423-7

4. Hanno PM. Intersititial cystitis and related disorders, in Walsh PC, Retik AB, Vaughan ED Jr, Wein AJ (Ed): Campbell's Urology. Volume 1, 8th edition. Philadelphia, PA: WB Saunders; 2002:631-70.

5. Parsons CL, Parsons JK: Interstitial cystitis, in Raz S (Ed.): Female Urology. 2nd edition. Philadelphia, PA: WB Saunders; 1996:167-82.

6. Parsons $\mathrm{CL}$, Rosenberg MT, Sassani $\mathrm{P}$, et al. Quantifying symptoms in men with interstitial cystitis/ prostatitis, and its correlation with potassium- sensitivity testing. BJU Int 2005;95:86-90

7. Dixon JS, Holm-Bentzen M, Gilpin CJ, et al. Electron microscopic investigation of the bladder urothelium and glycocalyx in patients with interstitial cystitis. J Urol 1986;135:621-5.

8. Nickel JC, Emerson L, Comish J. The bladder mucus (glycosaminoglycan) layer in intersititial cystitis. J Urol 1993; 149:716-8.

9. Anderson VR, Perry CM. Pentosan polysulfate: a review of its use in the relief of bladder pain or discomfort in interstitial cystitis. Drugs 2006;66:821-35.

10. Parsons $\mathrm{CL}$, Benson G, Childs SJ, et al. A quantitatively controlled method to study prospectively interstitial cystitis and demonstrate the efficacy of pentosanpolysulfate. J Urol 1993;150:845-8

11. Mulholland SG, Hanno P, Parsons CL, et al. Pentosan polysulfate sodium for therapy of interstitial cysitis: a double-blind placebocontrolled clinical study. Urology 1990;35:552-8.

12. Nordling J, Anium FH, Bade JJ, et al. Primary evaluation of patients suspected of having interstitial cystitis (IC). Eur Urol 2004;45:662-9

13. Schaefer $W$, Chen $Y$, Tadic $S$, et al. Urodynamic grading of bladder oufflow conditions in females. Abstract, International Continence Society Meeting, San Francisco, CA; 2009.
14. Griffiths D, Hofner K, van Mastrigt $R$, et al. Standardization of terminology of lower urinary tract function: pressure-flow studies of voiding, urethral resistance, and urethral obstruction. Neurourol Urodyn 1997;16:1-18.

15. Gajewski J. The patient presenting with painful bladder syndrome. In: Supportive Care for the Urology Patient. Richard W. Norman, David C. Currow, editors. Oxford University Press, UK; 2005.

16. Rovner E, Propert KJ, Brensinger C, et al, Treatments used in women with interstitial cystitis: the interstitial cystitis data base (ICDB) study experience. The Interstitial Cystitis Data Base Study Group. Urology 2000;56:940-5

17. U.S. Food and Drug Administration. http://www.accessdata.fda.gov/scripts/cder/drugsaffda/. Accessed February 18, 2011

18. Parsons CL, Mulholland SG. Successful therapy of interstitial cystitis with pentosan polysulfate. J Urol 1987:138:513-6

19. Fritjofsson A, Fall $M$, Fuhlin $R$, et al. Treatment of ulcer and nonulcer interstitial cystitis with sodium pentosanpolysulfate: a multicenter trial. J Urol 1987;138:508-12.

20. Held PJ, Hanno PM, Wein AJ, et al. Epidemiology of interstitial cystitis: 2, in Hanno PM, Staskin DR, Krane RJ, Wein AJ (editors). Interstitial Cystitis. London: Springer-Verlag; 1990:29-48

21. Jepsen JV, Sall M, Rhodes PR, et al. Long-term experience with pentosanpolysulfate in interstitial cystitis. Urology 1998;51:381-7

22. Nickel JC, Barkin J, Forrest J, et al. Randomized, double-blind, dose-ranging study of pentosan polysulfate sodium for interstitial cystitis. Urology 2005;65:654-8.

23. Hanno PM. Analysis of long-term Elmiron therapy for interstitial cystitis. Urology 1997:49(5A Suppl):93-9.

24. Holm-Bentzen M, Jacobsen F, Nerstrøm B, et al. A prospective double-blind clinically controlled multicenter trial of sodium pentosanpolysulfate in the treatment of interstitial cystitis and related painful bladder disease. J Urol 1987;138:503-7

25. Cameron AP, Gajewski JB. Bladder outlet obstruction in painful bladder syndrome/interstitial cystitis. Neurourol Urodyn 2009:28:944-8.

26. Dmochowski RR. Bladder outlet obstruction: etiology and evaluation. Rev Urol 2005;7(Suppl 6):S3-S13.

27. Schmidt RA, Vapnek JM. Pelvic floor behavior and intersitital cystitis. Semin Urol 1991;9:154-9.

28. Leppilahti $M$, Tammela $T L$, Huhtala $H$, et al. Prevalence of symptoms related to interstitial cystitis in women: A population based study in Finland. J Urol 2002;168:139-43.

29. Song $Y$, Zhang $W, X u B$, et al. Prevalence and correlates of painful bladder syndrome symptoms in Fuzhou Chinese women. Neurourol Urodyn 2009;28:22-5

30. Kennedy $C M$, Bradley $C S$, Galask RP, et al. Risk factors for painful bladder syndrome in women seeking gynaecologic care. Int Urogynecol J Pelvic Floor Dysfunct 2006;17:73-8.

Correspondence: Dr. Jerzy B. Gajewski, Professor of Urology \& Pharmacology, Department of Urology, Dalhousie University, QEIl Health Science Centre, HI Site, 1225B-1796 Summer St., Halifax, NS B3H 3A7; fax:902-473-8568; igajew@dal.ca 